\title{
On the Mariner's Compass in Modern Vessels of War
}

\author{
Staff-Commander E. W. Creak R.N., F.R.S.
}

To cite this article: Staff-Commander E. W. Creak R.N., F.R.S. (1889) On the Mariner's Compass in Modern Vessels of War, Royal United Services Institution. Journal, 33:150, 949-975, DOI: 10.1080/03071848909418092

To link to this article: http://dx.doi.org/10.1080/03071848909418092

册 Published online: 11 Sep 2009.

Submit your article to this journal $₫$

Џll Article views: 2

Q View related articles $\square$ 
Fridas, MIas 31, 1889.

ADMmal H. BOYS, Vice-Chairman of the Council, in the Chair.

\section{ON 'THE MLRINER'S COMPASS IN MIODFRN VESSELS OF WAR.}

Bj Staff-Commander F. IV. Cuesk, IR.N., F.R.S., Superintendent of Compasses at the Admiralty.

Ir is now serenteen years since the late Captain Sir F. Erans gave his last lecture in this Institution, on tho magnetisn of iron ships and the treatment of their compasses. It is true that during that period the improvement of the mariuer's compass as an instrument of navigation and the means of correcting its errors bave been the subject of various papers, but there remains inuch to be said on the increasing difficulties with which the compass on board modern ships of war is surrounded, and how those difficulties have to be met and orercome.

The Council of this Institution have done me the honour of inviting mo to read a paper on this subject, and I lave therefore prepared the following remarks commencing from the period of 1872, and in continuation of the paper before referred to. There will, consequently, be no need to entar into the historical portion of the subject, as it has already been so fully treated of in several papers written in Eugland, and also in that excollent introduction to the French translation of the Admiralty Mranual of 1870, entitled "Exposé IIstorique," by Lieutenant Collet of the French Nary.

In addressing an audience of my countrymen I need bardly make an effort to arouse a special interest in the subject of the compass in ships-of-war. We should know now-if not from our own conception of what is needful to the national safety-at any rate from the writiugs and speeches of numerous high anthorities, both political and naval, that we must lave a large and powerful narg, one part of it consisting of ressuls possessing considerable powers of resistance to the eflects of modern projectiles combined with high speed; the other part, a more numerous family of small lightly constructed craft of still greater speed and haudiness.

'I'his consideration of high speed points to the necessity of providing our ships with compasses of the greatest accuracy with which to navigato them, capable of withstanding severe vibrations of the hull caused by their powerful engines, and shocks from firing heary guns, while the requirements of a modem war ressel as regards dis- 
tribution of tho iron and stecl armour seem to vio with the previons considerations in rendering the task more and more one of care and judicions treatment. Let ns therefore inquire into the various causes of disturbance, mechanical as well as magnetical, and ascertain how far success has been attained in making the compass, in the midst of its numerous encmies, the instrument of precision we would fain have it.

Referring to the paper of 1872 , it will be found that after an examination of the macnetic history of a large number of iron ressels of the Fleet combined with the results obtained by tho Liverpool Compass Cornmittee, certain definite conclusions were arrired at of which the following are the principal :-

"1. The magnetism of irou ships is distributed according to precise and well determined laws.

"2. That a definite magnetic chnracter is impressed on ererg iron ship whilst on the building-slip, which is nerer afterwards cntirely lost.

"3. That in an iron-built ship and in that part of her within which the navigating or standard compass is generally placed, the polar force is that from the magnetisn of the whole body of the ship, and is nearly uniform; that we caunot escape from the nction of that force by any care in the selection of a place for the compass.

"4. That the definite magnetic character of an iron ship, so far as relates to the polnr forces dereloped in her during construction, is shown by the connection which exists between the direction of the ship's original magnetism and the direction of lier head when on the luilding-slip; for the original semicircnlar deriation consists princifrally in an attraction of the north point of the compass-necdle to the part of the ship that was south (or nearly so) in building.

"5. That a great reduction takes place in the magnetism of an iron ship on first clanging her position after lannching, and that her magnetism is then unstable for a short period. 'Then, after a few months' service, perhaps within a jear for tho arerage of ships, the time probably depending on the nature of the iron employed in the construction, the magnetism of tho ship ncquires a very stable chuncter.

"6. That in iron-built ships, as at present constructed, the ship's polar foree is gencrally so great as to make it necessary to emplos magnets to equalize the directive force on different azimaths of the ship's head, even at the most carefully selected position."

Of these the two first conclusions have been fully confirmed by olsservation up to the present time. Of Nos. 3 and 4 it may be said that they are ouly so far true, "that we cannot escrpe from the action of that force (the polar force of the ship) by ans care in the selection of a place for the compass;" but however carcfully the position of the standard compass may be selected in modern ships, it is very seldom that the polar force at that position " is that from the magrnetism of the whole bolly of the ship." Not mang years ago it was a mutter of simple calculation to ascertnin npproximatcls the direc. tion in which a ship had been built, if the deviation on two adjacent 
cardinal pointa of the compass were known, showing that the com. pass was affected by the whole body of the slip. Now, however, from the largely increased use of iron and stoel in tho shape of superstructures in turret-ships, conning-towers, iron masts, and deck cabins, the deriations observed at a standard position proceed from the hull largely dominated by that of the nearest. iron body. For example, the turret-ship "Hecato" was built with her head in a northerly" direction, and, according to conclusions 3 and 4 , the standard com. pass needle should have been attracted towards the stern. It was nerertheless attracted towards the bow by a force greatly in excess of the earth's dircctive force. Agsin, in the "Drendnought," built heal S.W., the attrection should have been towards the port bow ; whereas it was found acting strongly towards the stern, and, as in the former case, by $a$ force greatly in excess of that of the earth. Conclusion 5 may be considered as confirmed by tho experience of lator years to a great extent, but really before a ship is conmissioned she undergoes sach leugthened trials under steam at high speed, followed by gun trials, that she mas be expected to have assumed a fairly stablo mag. netic condition, and subsequent changes will occur very slowly, forming no source of anxiets to the ravigator.

The following conclusions are the results of a comparatirely recent investigation of the deviations of the compass at the standard positions of a number of ressels of different t5pes, which had during their commission traversed largo ranges of magnetic latitude duriug the jears 1871-83, and ainply confirmed by subsequent results up to the present datc. ' The list includes six armour-plated ressels, four of iron cased with wood, three iron troopships, three iron and steel cased with wood, and seven composite-built vessels. The deviations were not only analszed according to the usaal methods by which the several values of the semicircular and quadrantal components are ascertaived, but the semicircalar deriations were subjected to a further analysis, showing how much was due to hard and soft iron, or to iron of a character intermediate between what is known, magnetically speaking, as "hard" and "soft" iron. Always remombering that the obserrations wero made at standard positions carefully selected as the best available in each ship, the following conclusions wero arrived at:-

"1. A large proportion of the sornicircular deviation is due to parmanent magnetism in hard iron."

"2. A large proportion of the semicircular deriation may be reduced to zero, or corrected for all magnetic latitudes, by fixing a hard steel bar magnet or magnets in the compass pillar in opposition to, and of equal forco to, the forces producing that devintion."

"3. A very small proportion of the semicircular deriation is due to sab.permanent magnetism, which diminishes slowly by lapse of time."

"4. The sub-permanent magnetism produces deriation in the same direction as the permanent magnetism in hard iron, except when tern porailily disturbed, (1) by the ship's remaining in a constant positiun

-1 Sce ". Pbil. Trang. Roy. Soc.," 1S93, Part II, p. 615, et seq.

VOL. XxxIII. 
with respect to the magnetic meridian for sereral days; (2) by concus sions, (3) or by both combined, when the disturbance is intensified."

" 5 . To ascertain the full values of the changes in the sub-permanent magnetism, obscrrations should be taken immediately on remoral of the inducing cause."

" 6 . In the usnal place of the standard compass, the devintion caused by transient vertical induction in soft iron is small, and of the same value (ncarly) for ships of similar construction."

"7. The preceding conclusions point to the conditions which should govern the selection of a suitable position for the standard compass with regard to surrounding iron in the slip."

Now the establishment of conclusions 1 and 2 was rery important, for it. showed that the principal part of the magnetism of armour. plated ships like the ordiuars iron ship was nearly all permanent, and could be corrected once for all by permanent maguets, instead of "the amount of the induced and permanent magnetism" being "nearly equal," as was supposed in 1872-conditions which would have neces. sitated either the acceptance of a constantly changing deviation as the ship proceeded from high to low magnetic dip in one.hemispbere, and vice versâ, or the constant alteration of the correcting marnets as well as the application of a large Flinders' bar. One instunce of the latter complicated state of things in tho case of a Sir Willinm Thomson's compass, placed, for convenience of handling the ship, forward, abaft the director-room of the "Agamemnon," may serre to illustrate. When that ressel proceeded from Colombo to the Mlediterrancan, althongh 4 feet of Flinder's' bar were fixed to the binnacle, tho magnets required to be constantly changed to keep the compass errors within moderate limits. Here the changing part of the semicircular deviation due to rertical induction in vertical soft iron, rarging as the tangent of the dip, was largely in excess of that due to hard iron. On the otber hand, the "Imperieuso" has been to the Capo and then to Hong Kong with less change than many au old wooden ship.

Conclusions 3,4 , and 5 may be discussed together, as they all refer to the sub-permnnent magnetism of the ships. But first let us pause to consider for a moment the exact definition of sub-permanent magnetism as used herc. As already stated, a large portion of the semicircular deviation at the standard positions of our ships has been found to be due to permanent magnetism in hard iron, a small portion of it and the quadrantal deviation being due to the soft iron of tho ship taking ap and parting with its maguetism rery rapidly. Iutermediate between this strictly hard and oolit iron, and, fortunately, not evident in large quantities, there is found in every ship iron showing for a time the characteristics of herd iron, in causing polar deriations in the compass. It is, howerer, constantly liable to lose this polarity, either by lapse of time after the removal of the inducing cause, or its polarity may be reduced to zero, or tutally reversed instantly by shocks inflicted on the geveral structure of the ship. The amount of deviation produced by iron of this nature has been found to rary for each ship, and to range from $1^{\circ}$ to $6^{\circ}$ or $7^{\circ}$; a great deal depending upon the proximity to the compass of the surrounding iron. 
Now, no suitable corrector has as yet been found for doviations of this kind, and the only course open is that of constant observation and careful notation of the results for immediate and future use.

As ressels of war are specially under consideration, I would lay gtress on the effects of firing heavs gans with the ship's head in one direction. Sometimes the violent shocks which the ship receives altcr considerably the direction of the pull of the sub-permanent magnetism of the ship on the compass. The change gradually decreases in amount, occupying from a month or six weeks to a few days in returning to its normal condition. Considerable success in obviating these changes has been obtained by firing with the ship's head in rarious directions. For erample, when simultaneous broadsides of fro 13-ton guns were fired from the "Bellerophon" off Plymouth in 1886 , with the ship's head in opposite directions, there was no change of deviation. Other instances might be quoted in support of this.

On conclusion 6, I would remark that up to the present time, the deviation caused by transient vertical induction in rertical soft iron continues to be of moderate amounts at standard positions in most of our ships-a vers desirable result, considering that the use of correctors should be aroided when possible.

In dismissing that part of the subject relating to semicircular deriation, it may be said that, if sufficient care is exercised in prepar. ing a place for the standard compass, experience shows that in modern war-ships the sewicircular deviation is generally either of moderato amount, or of such a character that it can be corrected for all latitudes. Much may bo done in a sinilar direction for the stecring compasses, which are not very near thick vertical armour.

The ressels which have been thus treated of, hare always been considered to be upright, or on "even beam," as it has been aptly termed, and there are still certain difficulties to be overcome before we can navigate them safely by the cumpass. I allude more particalarly to the diminution of the mean directive force acting on the compasses at the protected positions on board our modern armourplated and armour-decled ships, the large values of the quadrantal deviation, the great increase of their heeling errors, and the evil effects of swinging ships other thun rery slowly in one direction, either to starboard or to port.

Before, howerer, considering these difficulties, I think my reasons for thus accentuating them so strongly shoold bo given, especially as at standard positions we are able to fairly sustain the conditions of twenty years ago; and no nntoward result to navigation has happened daring that time, depeuding in any way upon low directivo force, or quadrantal deviation. I beliere I am fully supported by many leading Officers of the day in the opinion, that compasses successfully placed in conning-towers and other protected places; so as to be nearly correct in showing the direction of the ship's head, and as a consequence the arc of the horizon through which the ship's head mas be turned, aro of the greatest importance. Compasses in our well-placed standard positions with closely corrected anxiliary compasses on chart-houses and bridges, from which all-round views $3 \div 2$ 
may be had, are all very well for taking the ship to the scene of action or for concerted mancoures of the fleet without an enerny in sight; but I do not think I detract from British pluck when I say that in face of an enemy within range well provided with quick. firing and machine-gans, the Officer who went to observe at the exposed positions would, besides probably finding the compass hors de combat, seriously endanger a valuable life far more useful elsewhere.

\section{On the Diminution of the Mrean Directive Force to North acting on the Comepass Needle.}

It has been thonght by many persons that as long as a position could be found in a ship where the deviations were moderate, or conld be nearly corrected, sach conditions were satisfactory for a compass used in navigating the ship. This idea is most illusory and eren dang'rous in its consequences, as it is casy to conceive a position where there may be no deviation, and yet the directive force is so luw that the compass is not only rery sluggish in action, but is liable to the effects of erery temporary change in the magnetism in the surrounding iron, and all its mechanical defects are rendered doubly apparent. The following table gives the values of the mean horizontal directive force to north, or $\lambda$ according to the notation of the Admiralty Manual, on board two of our modern belted crnizers, considering the earth's horizontal force $=1 \cdot 0$. In six of our battle ships the $\lambda$ at their standard positions raried from 0.800 to 0.855 , which may be taken as common values for that class of ship.

\begin{tabular}{c|c|c|c|c|c}
\hline Ship's nsme. & Standard. & Bridge. & $\begin{array}{c}\text { Conning- } \\
\text { tower. }\end{array}$ & $\begin{array}{c}\text { Fore } \\
\text { torpedo- } \\
\text { Ilat. }\end{array}$ & $\begin{array}{c}\text { Steam } \\
\text { steering } \\
\text { sft. }\end{array}$ \\
\hline "Orlando"......... & $\begin{array}{c}0.762 \\
0.822\end{array}$ & $\begin{array}{c}0.616 \\
0.618\end{array}$ & $\begin{array}{c}0.212 \\
0.2 .13\end{array}$ & $\begin{array}{c}0.660 \\
\ldots\end{array}$ & $\begin{array}{c}0.720 \\
. .\end{array}$ \\
\hline
\end{tabular}

It will be seen by these figures that whilst as a rule 0.8 of the enrth's directire force remains intact at the standard positions, only a little over 0.6 is found at the bridge compasses of the "Orlando" and "Undaunted." These latter compasses were placed on the fore bridge for convenience of stecring as well as for taking bearings when the ship is going in and out of harbour, and other pilotage waters. They are secured in positions 6 feet above the conning-tower which acts as a gigantic Flinders' bar below it. Descending to the conningtower, where the compasses are placed in the most adrantageons position near the centre, the mean directive force is foud to be only 0.212 and 0.243 respectively, or a diminution of rather more than three.fourtbs as compared with a position on shore. 'I'bus a conningtower with a plating of $12^{\prime \prime}$ thick and two-thirds of that thicknes 
very soft iron as in the two ships mentioned, is about as bad a place as possible for a compass eren when nearly corrected.

\section{On the Quadrantal Deriation.}

As long as the quadrantal deviation at any compass is not more than $8^{\circ}$, it may be considered as within manageable limits either for correction by soft iron or to be left for tabular correction. At standard positions in eight typical battle-ships, tho quadrantal deviation varied between $\bar{D}^{\circ}$ and $8^{\circ} 30^{\prime}$; but it is when the protected positions are examined, that the diflealties arise, for then we have gencrally a combination of limited space and large ralues of this deviation.

Table of Quadrantal Deviation, or Coefficient $D$.

\begin{tabular}{|c|c|c|c|c|}
\hline Ship's name. & Bridge. & $\begin{array}{l}\text { Conning. } \\
\text { tower. }\end{array}$ & $\begin{array}{c}\text { Fore } \\
\text { torpedo-Alat. }\end{array}$ & $\begin{array}{l}\text { After stesm } \\
\text { steering. }\end{array}$ \\
\hline 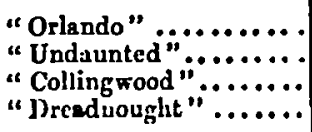 & $\begin{array}{c}+4^{\circ} 54^{\prime} \\
+47 \\
\cdots \\
\cdots\end{array}$ & $\begin{array}{c}+16^{\circ} 9^{\prime} \\
+160 \\
\quad \cdots \\
\cdots\end{array}$ & $\begin{array}{c}+18^{\circ} 56^{\prime} \\
\because \\
\cdots\end{array}$ & $\begin{array}{l}+25^{\circ} 33^{\prime} \\
+2030 \\
+2130\end{array}$ \\
\hline
\end{tabular}

The figures in the table show what is commonly fond in protected positions, and they convey the certain information that compasses with such errors, combined with low directive force, are of litile ase unless closely corrected. How this is to be done will be fully considered towards the close. The attempt was made to correct the 10-inch Thomson compass at the armour-cross of the "Agamewnon," only 12-inch spheres being used on account of the cramped space a railable, but large and most inconvenient quadrantal deviations of $16^{\circ}$ remained uncorrected, and the result was an undesirable compass for mancuvring purposes. Great efforts were made to correct a Thomson compass outside the conning-tower of the "Polyphe. mus," but they were unsuccessful, and the remaining deviations aro constantly. changing from the compass being so close to the iron. 'T'he ouly weans to obtain angthing like successful working, is to place the compass near the centre of the tower, for experiment has shown how futilo it is to place it near the sides. Two instances when the compass was placed very near the sides of the tower will suttice to illustrate this : (1.) The "Curlew," lying N. by W. On visiting the tower the movable top was lowered to its full extent, the compass, a 6-inch 'lhomson, pointed to S.E., the top raised 2 iuches, it settled at $N . E$., raised to 4 inches it showed $N$. by W.; in fact it was hard to make the compass point in any northerly direction at all. Tho correcting spheres too, became so stıongly magnetized by induction from the tower that they had to be re- 
moved as mischieronsly increasing the errors. (2.) In annther tower in the "Conqueror," merely raising the small shutters to lonk out, altered the Thomson compass inside three points. It is there. fure incumbent apon Officers in these ships to see that the mornble top of the towers should only bo raised to one determined height, if the compass inside and that above it, are to be of use.

\section{On the Heeling Error.}

As long as iron and armour-plated vessels were liable to heel under sail, the uncorrected heeling error was often a source of trouble, if not of danger to the navigator; especially if the ship were first on ono tack and then on the other. With the sail-less ships of to-day; these conditions no longer exist, but the uncorrected heeling crror has still a distarbing effect on the compass when the ship rolls, sometimes producing considerable oscillation of the card, or if that be apparently steady, an uncertainty in its pointing. As regards standard compass positions, the hecling coefficients have much the same values as in ships of trenty jears ago, seldom exceeding $11^{\circ}$, often much less, and quite within the limits of easy correction. Als with tho two other coefficients $\lambda$ and $D$, with which the heeling error is closely connected, it is when we approach the conning-towers and other protected places, that alnormal results follow. I do not think $I$ can place the subject more clearly before you, than by giving the details of experiments made last Jear, when the belted cruizer "Orlando" was actually inclined, and the results of a subsequent series of obserrations mado during her voyage to King George's Sound. This ressel, lying with her head magnetic south in Kegham Basin, was inclined $5^{\circ}$ to starboard, and $5^{\circ}$ to port, the ship's head by all compasses being noted for each degree as the ressel heeled over. 'The usaal' observations of vertical force wero also made when tho ship was upright. The calculated resalts from the force observations, and those from actual beel are shown in the table. Their agreement is not as close in all cases as I had hoped, but I do not think the late JIr. Archibald Sinith, who givo the formula, expected it to bo put to so serere a test. It is nevertheless a boon to possess so ready a means of obtaining approximate values without inclining tho ship-a formidable task for erery ship of the Navy.

'The Navigating Officer of the "Orlando" was furnished with the usual instruments for observing the horizontal and vertical forces, and he sent into oflice observations for Colombo and King George's Sound. Theso havo now been discussed with the following resulting table of heeling coefficients, in which those from actually incliningr the ship aro noted in italics :- 


\begin{tabular}{|c|c|c|c|c|c|}
\hline & Standard. & Bridge. & $\begin{array}{l}\text { Conning- } \\
\text { tower. }\end{array}$ & $\begin{array}{l}\text { Fore } \\
\text { torpedo- } \\
\text { flat. }\end{array}$ & $\begin{array}{l}\text { After } \\
\text { steum } \\
\text { stecring- } \\
\text { whecl. }\end{array}$ \\
\hline $\begin{array}{l}\text { Deronport.......... } \\
\text { Colombo............. } \\
\text { King Gcorge's Sound. }\end{array}$ & 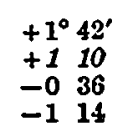 & 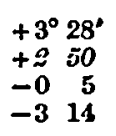 & 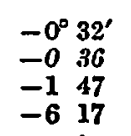 & $\begin{array}{ll}-1^{\circ} & 15 \\
-1 & 36 \\
-0 & 44 \\
-1 & 30\end{array}$ & $\begin{array}{ll}-1^{\circ} & 11^{\prime} \\
-0 & 40 \\
-0 & 38 \\
-1 & 13\end{array}$ \\
\hline
\end{tabular}

To take ono example-the abore figures show that at the bridge compnss when the sbip heeled orer $10^{\circ}$, on a north or south point, the hecling error would be about three points to the high side in Eugland, and about three points to low side in Anstralia-a change of six points if not kept frequently corrected by magnets at different positions during the royage.

The next table shows the relative portions of soft and bard iron in the vertical force of the ship, which is the principal element in producing the heeling error, $k$ representing soft iron, and $R$, hard iron; and the rertical force in England being taken as 1.0. IR may be corrected for all latitudes by a permanent magnet placed rertically under the compass; $k$ should, according to the law that "like cures like," be corrected by a vertical soft iron bar. It is, howorer, moro conrenient to use a permanent magnet vertically below the compass, and alter its distance therefrom as necessary.

k.

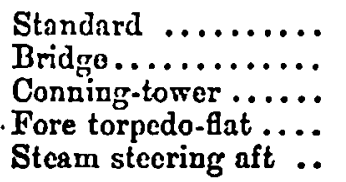

$+0 \cdot 136$

$+0.419$

$-0.557$

$-0.474$

$-0.545$
R.

$+0.019$

$-0.318$

$-0.414$

$-0.387$

Note.-The sign + denotes a downward force, the sign - an upward.

At the bridge compass rnised 6 fect abore the conning-tower tho heeling coefficient is shown to be abnormally large and cbangenble in character from its being almost entirely due to rertical induction in soft iron, the value of $k$ being +0.419 , of $R$ only +0.019 , which, added to the constantly changing deviation from the horizontal forces, makes the position one to be carcfully aroided, except for stecring parposes. It is truo that as long as the ressel remained in one magnetic latitnde, a compass in such a position might be kept with errors of a moderate amount, but the "Orlando" is a ressel intended for possible rapid changes of magnetic latitude, and it ronld thereforo prove a rery uncertain compass to trust to. There was, however, a standard position in this ship as usual, where tho compass appears to have remained constant in its doviation bejond expectation. 
Inside the conning-tower no hecling error of large amount wan observed until the ressel renched south dip, and at King George's Sound, it assumed the unprecedented value, as far as I am aware, of about five points for 10 degrees of heel.

At the other protected positions below, the heeling errors proved more constant than at the standard, and capable of easy correction by i magnet.

Taking a general view of the results in the table, it may be remarked, that thick armour plating ippears to be the chicf cause of difficulty when dealing with a compass, as magnetically speaking it is almost entirely composed of soft iron, scriously reducing the directive furce on the needle whilst producing large deviations of a cunstantly changing character.

\section{On Electric Lighting of Tessels.}

When evcrything bas been done by carefully placing the compres, removing all the iron possible from its vicinity, and applsing the necessary correctors, there still remains another. source of dauger to its successful working to be guarded against, which has urisen from the introduction of the electric light on board ship. Fortunately, experiment has now shown that with a well-designed installation, all trouble may be aroided, but $I$ think it would be a want in the present paper if the resalts of experiments, and the sources of danger which hare been discorered, were left untold.

The two causes of disturbance are the dynamo and bingle wire leads. Thas, cxperiments on board the "Euphrates" showed that; the polarity of an Edison machine affected a compass at a distance of over 40 feet, and instances of disturbance from the dynamo in other vessels have been observed. Of the effects of single wires, an experi. ment on board the "Rogalise" may be cited. One wire was lead under the standard .compass at a distance of $13 \mathrm{feet}$, the return wire " as separated only 5 . feet from it. With a carrent of about 100 ampères, a deflection. of $8^{\circ}$ was obserred in the compass, which prored an excellent galvanometer, the deflection increasing and decreasing for erery rariation of the current without oscillation. In our present state of knowledge, the prudeut course appears to bo to aroid tho use of dynamos of large external field, to keep these unchines at least 35 feet from the compass, and to take care, as far as possible, that buth poles of the machine be at equal distances from the compass. It has been thought that iron bulkheads and decks would so alter the direction of the exterual lines of magnetic force of the machine that they woold nct as screens. This suggestion has not been borno out by experience and suitable magnetic screens have jet to be devised.

As regards the wires, the use of single wires with hall as return is to be deprecated, and the lead and return wires should be kept close tugether and carefully insulated.

I have used the expression "our present state of knowledge" in order to aroid any appearance of wisling to gire a law for a matter 
connected with electricity, a branch of science which mores onward t so rapid a pace.

\section{On the Effects of Suinging Iron Slips only in one Direction.}

I am not aware of a better nucans of illustrating the effects of swinging iron ships otherwise than very slowly in one direction, than that of bringing before you nome of the results of a series of observations made on board the "Intlexible" in 1882. The compasses used were the Admiralty standard in one position, and a Sir W. Thomson's compass in another; the observations being made by the azimnth instrument of each compass, so that no errors due to comparing one compass with the other could creep in. It was generally found, that when the ship was swung opposite ways, to starboard and to port, on the same duy, there was often a difference of at least $2^{\circ}$ in the deviation for each direction of the ship's head at both positions. As much as $4^{\circ}$ between the swinging to starboard and to port was found at a compass, when the surrouuding iron was near and unsymmetrically ciistributed. The series of deviation tables from tho "Intlexible" are rery instructive, and form a valuable record of scientitic and practical interest. The ship appears to hare been swang in the usual manner as regards time, but it is evident that a ressel with sach thickly-armoured decks and sides, and iron so close to the various compisses, must either be swung very slowly and steadied on each point, so as to allow the iron not strictly" "soft" to take up tho proper amount of magnetism dae to the direction of the ship's head, or she must. be swung opposite ways, and a mean result taken for the correct deviation. It should be borne in mind that the case of the "Inflexible" is one amongst many others, and the lesson to be learnt is applicable to all iron vessels of the present daj.

\section{The Disturbance of the Compass on approach to certain Shores.}

The mariner's compass has yet another enemy to contend with in the magnetic disturbance caused by prosimity to land. This reported disturbing effect is not now brouglit forward as a novelty, in fact it is an old stury often told and discredited by many whose opinions were well wortly of consideration. Well authenticated reports of recent years show that both those who doubted and those who reported were buth partly right and partly wrong. 'The facts are these: it is seldom, if ever, that the risible laud disturbs the compasses of a ship, as her distance from the shore would almost in every case entirely keep her out of its magnetic influence. It is the submerged land near the ship's bottom which, possesned of magnetic properties, sometimes of atiraction, sometimes of repulsion, produces the observed elfects on the north point of the compiss.

Now, I have brought this part of the subject forward, in order to place a clearly proved fact on a proper basis, and not with the riew of alarming the scaman. We have now a list of localities, situated in different parts of the world, where the disturbance of the compass has 
been noted by trustworthy observers, and I would raise a note of warning to navigators, prone to shave corners on a dark night, guiding their ships solely by the compass, that the rocks they approach with ample water orer for the ship to float and be safe, may be so strongly magnetic as to deflect the compass, carrying the ship into serious danger if not destraction.

Observations tend to show that magnetic rocks in the northern bemisphere attract the north end of the wecdle, and tberefore a ship nearing the land in moderate depths of water, say under twenty fathous, on northerly courses, would be drawn nearer and nearer to them. In the southern hemisphere the conrerse appears to hold good, the north end of the needle being generally repelled, and a ship steering on southerly courses might be liable to close the land without her Officers knowing anjthing about it. There is no need bere to enlarge upon the results of an iron ship's merely touching the ground, mnch less striking on a rocky botton. Tro well-established examples of disturbing localities will help to illustrate the foregoing remarks, which are the outcome of considerable inquiry.

The first is the case of our surveying vessel "Meda" at Cossack in North Australia. Here, with the visible Innd three miles off, the "Meda," running on a transit of two objects on shore, in 8 fathoms of water, had her compass steadily deflected $30^{\circ}$ for a quarter of an hour during which she stiiled over a mile.

'The nest instance is thist furnished by obserrations of the rariation of the compass on the Liast Coast of Madagascar. The normal lines of the variation for sereral miles of the coast from St. Mrary's Isle sonthward should vary from about $11^{\circ} \mathrm{IV}$. to $12^{\circ} \mathrm{WV}$., but instead of this the French men-of-war, which are frequently running up and down this part of tho coast, find that the rariation near the shore at St. Mary's Isle is ouly $6^{\circ}$ or $7^{\circ} \mathrm{W}$. and $12^{\circ} \mathrm{W}$. at $80^{\circ}$ south, the north end of the compass being repelled by the magnetic properties of the bottom. These results are analogous with those of observations on shore in Madagascar, New Zealand, and otber places.

\section{On the Mragnetic Character of Torpedo-boats.}

As torpedo-boats aro an entirely norel form of fighting ressel, introduced since the paper of 1872, a few remarks on their magnetic character may be acceptable.

It may be said at once, that with the standard positions there is every reason to be as fully satisfied as with those of any other iron vessel. The semicircular deriation seldom exceeds $12^{\circ}$ or $14^{\circ}$, the quadrantal is generally $+4^{\circ}$, and the mean directive force is satisfactory. The compass, therefore, is easily corrected by magnets and soft iron; the small remaining deviations of about $2^{\circ}$ being fairly permanent in spite of the constant vibrations to which the boats' hulls are subjected. Tho steering compasses havo generally to be placed near the sides of the turrets with semicircular deviations of some $30^{\circ}$ or $40^{\circ}$, the maximum of quadrantal deviation being sometimes $8^{\circ}$ or $10^{\circ}$, at others $3^{\circ}$ or $4^{\circ}$; but this is a subject which is 
receiring attention, with a view to placing the compasses in more satisfactory positions.

\section{Modern Systems of Correcting the Deviations of the Compass.}

Very little has been said as yet on the question of correcting the errors of the compass, but the readers of the Journal of this Institation will remember how fully Sir William Thomson deseribed the ananner in which ho had applied Sir G. Airy's system of correctors to his patent compass, as well as the Flinders' bar.' Subsequently to this, in the Journal for 1882, there is a paper by myself, "On Cornpass Correction in Iron Ships." I, therefore, proposo to confue my remarks to the latest plase of the question.

It is commonly remarked, that either a compass is sluggish and will not more, or that it is excellent and moves directly the ship's head moves. Now the ideal compass on board ship is one in which the card refuses to move at all, and stendily and strongly points to magnetic north while the ship and compass bowl torn round it as required by those in command. It should have no work to do in the shape of turuing to starboard or port, to bow or stern, in obedience to the magnetic forces existing in the ship, and the directive force of the earth should be interfered with as little as possible. How far the cornpasses ou board our iron and armour-plated vessels fall short of this ideal is shown by their deviations, which, at best, aro but rednced to a small amount for a giren time and place, whilst constancy of deviation may be said, as yet, to be unattainable.

The reason is obvious: the correctors we use are constant in their action, whilst a portion of the magnetic forces they aro intended to oppose is for the most part variable in amount and direction. With well-placed compasses there should be no difficalty in redncing the deviations to a minimum amount of $2^{\circ}$ or $3^{\circ}$, subject to changes from firing heary guns and ranning for some time on one course; it is when we come to conning-towers and other protected places that tronble arises, first in making the correction and afterwards mnintaining it. Our difficulties lio in the correction of largo quadrantal deviations ranging from $12^{\circ}$ to $30^{\prime \prime}$, and increasing the low directive force. The polar deviations must be left to the care of the magnets, but let us inquire what can be done for the quadrantal.

Beginning with the best form of Sir WV. 'Thomson's compass-the 10"-and supposing that the "Orlando," as a typical ship which wo know so well, is provided with them on the bridge, in the conningtower, and the two protected stations below, what happens? At the same time bear in mind that Sir W. Thomson lajs special stress on the close correction of his compasses, for he naturally wishes them to be like the ideal compass just mentioned and inexorably point to the north.

At the bridge compass the quadrantal deviation is only about $5^{\circ}$, and can be readily corrected by a pair of $7^{\prime \prime}$ spheres, which aleo help to correct about $44^{\prime}$ of heeling error for every degree of heel on

2 See papers of Februars, 1878, and May, 1880. 
the north and south points till the first $5^{\circ}$ of heel are reached, but gradually decreasing in theit power as correctors as the ship inclines further. Inside the conning-tower, the quadrantal deriation is a little ovur $16^{\circ}$, requiring a pair of $18^{\prime \prime}$ spheres to correct it. 'I'hese splecres add about $1 \frac{3}{4}^{\circ}$ of heeling error for every degreo of heel.

On the fore torpedo-flats the quadrantal deriation is $19^{\circ}$, requiring correcting spheres of $20^{\prime \prime}$ diameter, and adding largely to the heeling error which might otherwise be kept nearly correct in all latitudes by a permanent magnet.

At the after stenm stecring wheel the $26^{\circ}$ of quadrantal deviation must hare at lenst $2 t^{\prime \prime}$ spheres, again adding largely to the otherwise moderate heeling error.

Again, the effect of spheres is to reduce the directire force on north and south courses, and to increase it on east and west, their geueral effect being to slightly increase the mean directive force to norti on the compass, to correct the quadrantal deviation, and to introduce hecling errors sometimes of a beneficial order, bat in some cases producing adverse complications.

In positions below such as we have considered, and specially in conning-towers, the groat size of the spheres required for accurate correction makes their use almost prohibitive, aud in many ships there is no room even for tho moderate sizes. Moreover, we bave scen that the directive force is so low that one instinctively inquires why cannot these large deviations be corrected by somo system which requires small space, saj, within a circle of 20 inches, and at the same time sensibly increases the directire force which is so sorely needed ?

By reducing the size of the compass somewhat, I have reason to believe these objects may be attained, and the compass card may be giren needles of great directive force, which, instead of being a hindrance to correction, are a benefit.

In order to possess clear views of the quadrantal corrector I am about to deacribe, a short explanation of the principles upou which it is based seems necessary.

The well-known example of soft iron rods, placed in a horizontal plane passing through tho needles of a compirs, will help towards this

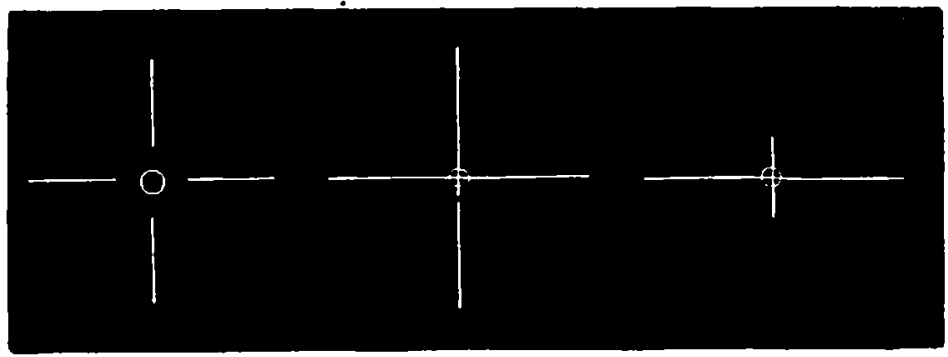

210. 1.

510. 2.

5.e. 3. 


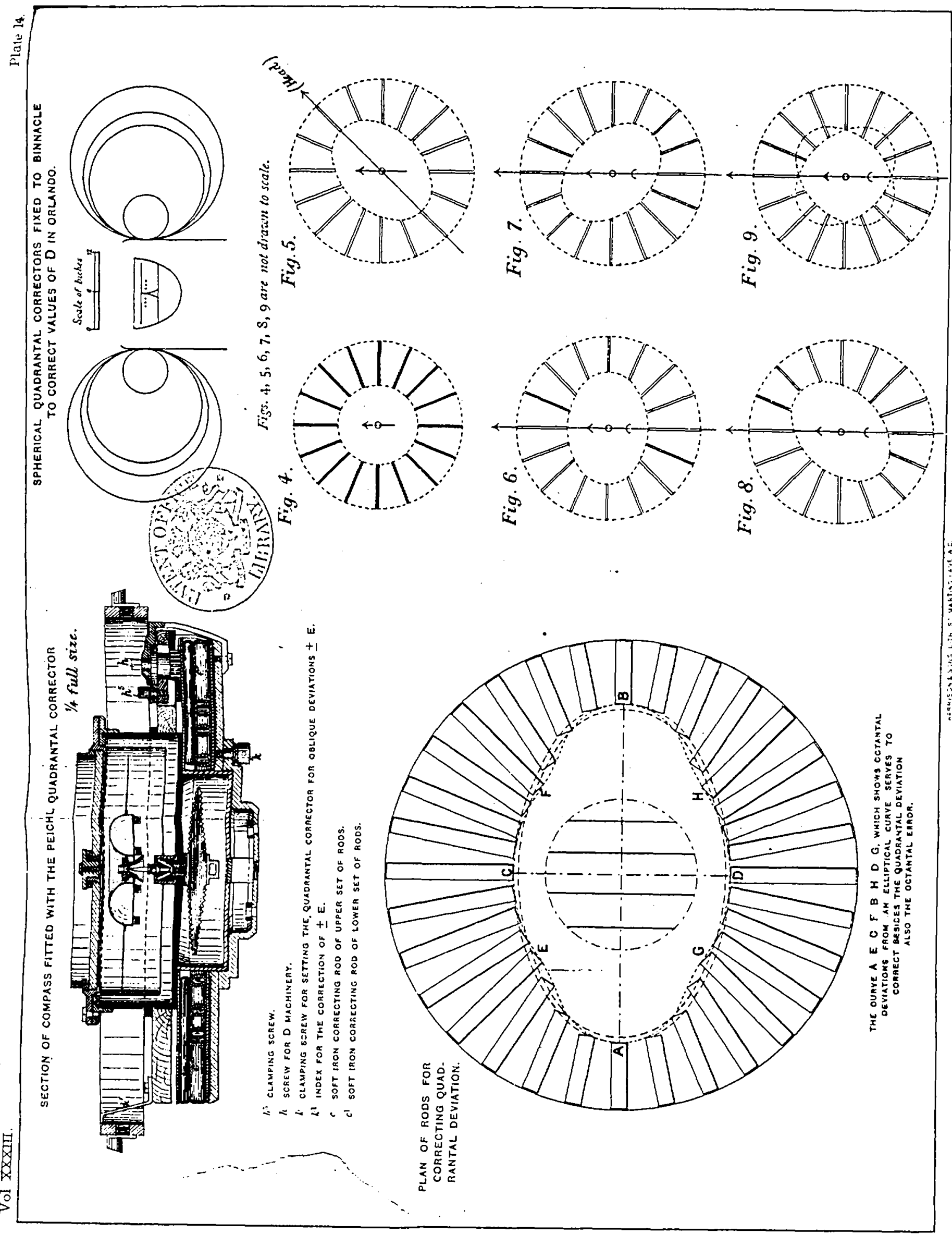


purpose. Thus, in Fig. I, the equal rods increase the directive forco but produce no deviation. In Fig. 2 the equal rods decrease the directive force but produce no deviation. In Fig. 3 the transverse rod is much longer than the longitudinal, and the deriation of the com. pass is caused as well as loss of directive force. It is soft iron. repregented by rods of the type Fig. 3, which produces the low directive force combined with large quadrantal deriation on board ship. Therefore, reasoning from the effects of the rods in Figs. 1 and 3, we baro only to place round the compass soft iron rods of the type Fig. 1, bnt of different lengths, so as to cnunteract the forces of the nnequal and detrimental iron of the type Fig. 3. This snlution of the difficulty of correction has been most clererly worked out by the Chevalier Peichl of the Austro.Hungarian Nary, and a compass with corrector, invented and patented by that Officer (sec Plate), lies beforc jou on the table; but as the system of soft iron rods is conccaled by the woodwork, reference mast be had to the diagrams for explanation. I maj remark here that this corrector has been adopted for five jears in the Austro-Hungarian Nary with great snccess.

Using the notation of the Admiralty Manual which is now common to the world, the parts of the quadrantal deriation are known as coefficients $D$ and $F$. The following is a translation of the inventor's description of the instrument :-

"The quadrantal corrector forms the principal part of the instru. ment in question. The action of this corrector is easily derived from the following considerations : an arrangement of perfectls soft iron rods, and of equal dimensions, disposed radially round a compass at equal distances from the card (Fig. 4), can produce no other effect than that of increasing the directive force, for then it is only a multiplier of intensity. But if, on the contrary, these rods were no longer equal in such a manner that their interior ends form an ellipse (Fig. 5); of which the major axis is parallel to the kcel, that different arrangement will produce a multiplier of intensity which nt the same time will be capable of compensating a given value of the positive quad rantal deviation, since it produces a negatire $D$. In the positions of this arrangement shown by Figs. 6,7 , and 8 , the effects are $+\mathrm{J},+\mathrm{F},-\mathrm{F}$; and in the intermediate positions, the relative portions of $\mathrm{D}$ and $\mathrm{E}$ will result. Now the quadrantal corrector consists of two sets or systems of soft iron rods placed one above the other, and movable in opposite directions round the compass borl. Fig. 9 represents their position when the index is nt zero. One sees by that that they produce $+\mathrm{U}$ and $-\mathbf{E}$, and that consequently their total effect in that position is nil. By turning them in the direction indicated by the arrows, the position will be reached when the major axes of the two ellipses are parallel to the keel. This is the position of their maximum effect, and it is marked on the index as 1.0 . The value of this maximum effect depends upon the details in the con. struction of the instrument, that is to say, on the length of the bars, and the distance of their interior ends from the card respectively with the form of the ellipse."

The action of this corrector is due especially to the indaction of 
the compass needles in the soft iron rods. This necessitates an arl. justnent of the corrector on change of latitude, for which an index and scale aro provided for all latitudes, and is of a very simple nature.

"This quadrantal corrector produces an increaso of directive force for erery direction of the ship's head."

I have experimeuted with this instrument in the conning-tower of the "Medusa," and I found I could correct $30^{\circ}$ of quadrantal devia. tion for all latitudes, and for the coasts of the United Kingdom about 41. These adrantages, coupled with the increase of directive force on all arimuths, and the small space occnpied, have led me to hope that this instrument will meet a deficiency in our present compass equipment. Before concluding the description of this corrector, I inay point out another valuable property connected with it. As the ship proceeds to parts of the world such as Quebec and the St. Lawrence, where the horizontal force of the earth is smaller than in Englaud, so the directive force of the instrument increases, making the compass point with greater energy than with any other system.

In a paper read last month at the Institute of Naral Architcets, Mr. W. W. Rundell, who mny be styled one of the fathers in compass matters, discussed the question of correcting certain compass errors caused by iron unsfmmetrically placed near a compass. His arguments tend to show that these errors are such as would be produced by one horizontal and one rertical bar of soft iron mnym. metrically placed, and that the corrector should be an inclined bar of soft iron, the position of which is to be found from an analysis of the obserred deviations. I am testing his propositions experimentally, but am not jet in a position to give an opinion upon them.

\section{General Obserzations.}

Fivers now and then it is reported that the mariner's compass which has served the navigator on the ocean and the traveller in the trackless forest so faithfally for handreds of years is about to be superseded by an instrument which shall always show the true north. The idea is captivating, and its realization would be a boon when we call to mind what has beev said of the compass in ships of war. Such an instrument therefore must be independent of all magnetic influences. It is true that in 1852 Léon Foucault showed that the grroscope takes up a direction parallel to the earth's axis. Foucault writes: "Then without the help of any astronomical observations the rotation of a body at the surface of the earth suffices to indicate the plane of the meridian." Sir W. Thomson, at a meating of the British Association in 1883 , also described a form of gyroscope, which, when rapidly rotated, showed distinctly the direction of the true neridian.

The question as to the motor of such an instrament, which should at once be antomatic and continuous, has not yet been answered,; and I think we shall for the present do wisely in treating the compass fairly, knowing full well that the earth's magnetic force is ever present to direct it. 
The words "Mariner's Compass" corer a great rariety of means for utilizing the one great principle of the earth's directive force, in the shape of a large number of compasses patented and otherwise. Finality has not been reached by any one of them, nor is it likels to be. Still we must always feel grateful to inventors for the many raluable aids they have provided for safo navigation; but those wha hare to report on inventions, and have the good of the Service at heart combined with due economy, must always bo on their guard, remembering that tbey have to deal with individuals often pleasant, persunsive, persistent, aud perceptive of ererything but possible faults in their iurentions. Amongst the many patents, I will only mention Sir IV. Thornsou's compass, the valuable qualities of which under certain conditions aro so well known and require no special wotice here.

There is another compass to which I rould draw attention, and that is the liquid compass, which, if properly constructed, is one of the most generally useful instruments of navigation set made. In torpedo-boats, and somo of the latest types of fast cruizer steaming under forced draught, tho liquid compass has acted well when erery other compass failed to a serious extent or was practically unservice. able. It has been in general use in the United States Nary for many Jears, and in their official book of "Notes on Chronometers, Com. passes," \&c., the following occurs: "It may then fairly be concluded that the United States Navy is possessed of a compass unsurpassed in its essential qualities by those in other serrices whether naval or mercantile."

It is used universally in the Austrian and German Navies, and also as a standard compass in the Italian Navy, I, therefore, suy without hesitation, apart from such witnesses to its value, that wo must hold fast to such a friend in need as it has lately proved, doing ail that is possible to perfect it as a part of the necessary equipment.

As to the placing and correction of compasses in our vessels of whatever type, the departments at the Admiralty are working heartily together. The Controller of the Nary, at the request of the Hydrograplier, has lately issued revised instructions to mect the requirements of the day, with a view to providing as saitable places for all compasses as the fighting necessities of a war-ship will permit. With the sources of error thus eliminated as far as may be, the work of providing suitable compasses and correctors is a constant subject of carnest enquiry in the departenent to which I have the honour to belong, and the strength or wealness of the several compass positions is fully proved.

It is not necessary to ascertain the magnetic character of every ship as has bcen done in the "Orlando" and "Uudaunted," as a number of ships of one class or type are generally built, and the full knowledge of one or at most two of each type furnishes all the most useful and necessary data for the rest.

The care thus bestowed is none too much, althongh it is sornetimes asscrted that correctors can do anything - and, lest a good way should come to be eril spoken of, I will quote a few lines from a work pub. 
lished by the United States Bureau of Narigation after they had made a searching inquiry into the subject of compass errors, and their treatment in iron and steel ships:-

"From all that precedes, it will readily be inferred that to place compass where the magnetism of the ship will least affect it, in essential both to the safety of the ressel, and to the good behavion? of the instrument itself." Again, "Compensation of large deviations by means of mngnets is at best but a renedy for an ailment; better not sow the seeds of the disease."

I should add that this inquiry was accompanied by experimental tests of the truth of Arcbibald Smith's mathematical theory of the deviations of the compass.

There is yet another point apon which $I$ wonld make a few short remarks, that is on the constant changing of the correcting magnets of the standard or navigating compass, by which the ship's course should be shaped, eren if not ro conreniently at hand as the badly placed auxiliary compass. The word "standard," as here used, refers to a position, not to anj particular form of compass.

If the clanges of the semicircular deriation range from zero to $4^{\circ}$ or $5^{\circ}$, I think it much more advantageous to leare them alone, and trust to freqnent observation for ascertaining the deriation, entering each observation in a compass journal for futuro reference. Should the semicircnlar deviation change largely and permanently, it would, no duubt, be right to correct it, taking care to swing the ship immediatrly after to ascertain remaining deviations.

These recommendations do not refer to mancourring compasser, which it is most convenient to keep as nearly as possible correct, Commanding Officers giring opportunities for making the corrections as required.

As to the compass journal, it is largely used in the narigation of the many noble ressels of the mercantile navy, and a constant changing of magnets is generally deprecated by their eminently practical commanders.

Touching the question of education in matters relating to the compass, erery means las been adopted for imparting sound information to Officers. At the Rojal Naral College, Greenwich, the seniors find able instruction of a most practical kind. At the College in Portsmonth Dockyard, every Sub.Ijientenant goes through a most userul course, illnstrated by models and practical adjustments in an iron gunboat at Spithead. They are also supplied with a pampllet of instructions in compasses and their treatment in iron ships, issued by order of the Admiralty.

After all that has been said, true science teaches us a nerer-to-beforgotten lesson. Observe the deviation when possible, note it in a book, and learn its changes under every circumstance as you do the rate of a chronometer. Then on some thick dirty night, the reward wil Jeome in the shape of a reasonable confidence that you can stecr the required course without delay and detriment to the service upon which the ship may be ordered. 
The Cusinsax: I may take this opportunity of saying that I hare receircl a note from Sir William 'Lhomson, nddressed to tho Chairman, regretting not being wle to be present to.day. I am sure you will all join in that regret.

Adniral Sir Enasyts Oyysxser, F.R.S.: I am rery glixd to find that wo hare this subject brought before us again after such a long interral, for it is now serentecu fears since Sir Frederick Erans delirered a most instructire achlress here regardling the manctization of iron ships and its effect on the stecring compasses. J)uring this interral a wonderful alteration has been progressing in the construction and in the metal of iron ships, likewise in the improrement of stecring compasses; we aro therefore grateful to Captain Creak (the able successor to Sir F. Lraus) for the instrustire paper we hase now heard, containing so much scicntific and practical infurmation of grcat raluc. I will not attempt to criticizo this papse, coming from such :n cminent cxpart as Captain Creak, than whom there is no higher nuthority in 19 bingdom on this important question. In my opinion the author of this paner has put the whole untter beforo us, as it now stands, most completely. I negret to obserre so few naval Oafiers present. Let us hope this papar will be read elsewhere, rery crteusively, beyond this room. The influenee and effect of magnetism, which operates so mystcriously and inrisibly orcr the surface of the earth, nenders it more incunbent for the marines of the present diay to sludy moro attentirels this branch of science and the propertics of this scerct ancat which posiesses an indiriduality in erery metallie ship which trarerses the wide occans, in order to secure accuracy for its narigation. I am sure we are all much indebted to Captain Crual for producing this rers instructire paper.

Captain Wrasiox (IIydrographer to the Tary) : Cilptain Creak's rery able and lucid paper so fully corcrs the ground and opens up so many questions that there is not much left for me to sas. I mas remark in starting thit I heartily agreo with all that ho has said, although $I$ do not pretend to bo such an authority on the subject as he is. I think he rers prominently brought to ererybody's inind the enorinous difliculties that there now are in correcting cumpasses on board our men-of-war. For some years there hare becn difficulties, but it is not too much to say that they increase erery day. There is no doubt that in war-time the compass you will want is a compass that jou can depend upon in a conuing-tower, and these are just the cornpasses I $\mathrm{nm}$ sorry to 825 that at the present woment are not at all reliable. The admirable inrention of Sir William Thomson fuils there, because in theso protected positions, as Captain Creal showed, you hare not room to place a compass with large spheres. Thoso enormous spheres not only take the whole space in these limited towers, but to a certain extent they introduce crror. Captain Creak referred to the intention of Cheralicr P'cichl, whoso compass has been introdueed into the Austro-IIungarian Nary for the last five Jears. I beliere it las becn under the consideration of the duniralty Dearly us long as that, but recent improrcments of JIr. Feichl's laro led Captain Creal to male further cxperinents, the results of which are so cucouraging that me are getting some more of them orer to try in our ships and test their efficacy thoroughly. If it answers ns we hope, it will go rery far towards solring that most important question of getting the compnss to work in these extremely nwlward positions with large masses of iron near it, and at the saune time it will tako up less space. I onls hope our anticipations may be justified. I mas mention in connection with the difliculty of fxing the position of a elip that I hare been for some time most anxious mhenerer there is an opportunity to inculcatc the uso of the station pointer. I am lappy to say these instruments are now being issued to all ships, and I hope with a littlo practice we shall come to recognize the crtreme ralue of that system, which in time of rar, in action, and also in time of peace, in ships where there are 80 many obstrüctions to clear riew from tho conipuss, enables jou to fix the position cxtrenely accurately from citber a protected position or a position where, by inclining Jour head a little, yon can sce the objent which in a nodern ship of war jou cannot possibly get from many of the compasscs. Captain Crcak has brought forward the question of the disturbance of the compass on approaching shore. For a loug tinse it wis thought not possible that the compass could really be disturbed. BJ well-knonn mignetic liws the ephere of influence of any disturbing forecs is so small that it ras felt quite impossible that tho compass pascing a point of land should erer be disturbed by the

roL. XXxill. 
magretic clinacter of the rock. But in some extraordinary manncr it las been orcrlooked that while a ship is a long distance horizontally from Iand, she may be passing rery closely rertically over it in shallow water, and it has only been recently recognized that this is the truc cyplanation, amd that thero realy is a danger in certain places, the inajority of which are quite unknown, in passing over slanlow water, of the compass being ecrionsly deflected. I belicre now that it is buown it will be borne in mind. I can only conclude by saying that I lope that our motto will alwass be "Onward." Finality is by no incans reaclied. Ile lave a rery difficult task in deciding what is the best form of inrention to tale up. It is very slow work indecd experinenting, but I fecl rery safe with Captain Creak ac the hiod of the Department looking after it. I linow lhat he has not only a vers open mind, but he has the fullest knowleclge of the subject, and I hare erery hope in time that we shall arrire at a more satisfactory condition of the complass in awh ward positious than I am afrid exists at the present moment.

Cuptain Ilares: I wish to bear testimony to the great ralue of the paper real by Captain Creak. It shows the difficults there alwajs has becn to correct the derintion of the compass in positions where the space is limited in iron ships. It is too technical a subject to go into rery much, but $I$ will just mention a few things that I lase noticed. Calphain Creak spolio of permanent and sub-perumaner. magnetism. In the rery carlicst diys, Sir Gicorgo Airs, Astronomer lioyal, spotac of a part of the magnetism of an iron ship as "permancnt." He afterwarls thought proper to chango the tern to "sub-permancut." From that tiunc to this there fias always been a doubt in the minds of many people as to which is "suv-permanent" and which is "permancut" magnetism. I caunot holp thinking if we use the word permanent only, instead of permanent and eub-permanent, we should be able to cxpress all that is required, recollecting that the magnelism of a ship is, litic most sublunary things, permancnt only for a time. The correction of the liecling error is unsutisfictory, and the formula giren by IIr. Archibald Smith does not apjear to be correct. I hare alwars found a dillicults in dealing with it, and I do not think that dificulty is quite got orer yet. With rigard to the clectrie light, when firat it was introduced into the Scrice, electricians were rery confident that the iron about the dynamo rould conduct atray and shicld the compass from all disturbinis influenecs. Iut they scemed to forget that we are deuling with mannctic force and not electric forec. IIagnetic foree mny be transposed but camot be eut off by iron. The only way 1 can sce out of the diliculty is to interrene between the conipasses and the dyamo a bar of iron so magnetized by a wire carrying a current wlien the dynamo is running, as to set up a counteracting magnetic feld. THere is no way of insulating it that $I$ can sce. The effect of swinging the ship to port and starboard was bnown many gears ngo. It wa first epolicn of by tho Liverpool Compass Comnittec. Thio "Defence" mas swung in $186 j$ both ways, showing a maximum difference of $3^{3}$, the maximum bcing on the north and sonth points. I lnare nerer seen an cxplanation of thiz disturbance of the necdle which has quite satisfied me. With regarel to the disturbing effect of land upon compasses, that has been known since the early part of the ccutury; but as the IIydrogapher say, it was generally forgotten that land was rery ucar the ship sometimes when it was spoken of as being miles awas. When men spoke of land, they thought of dry land, not of the wet land umler the ship's bottom. With regard to torpeclo-boats, some liare becn swung after rarious intervals of time, and I hare been much struck with the rery great permanence of the deriation of their etamdard compasses. The compass in the conning-tower presents insuperablo dificulties for want of space wherein to apply the necessary corrcctors, cren to tho smallest compass. Captain Creak hins alluded to a rccent paper by Mr. Rundell. I may state with refercnee thereto, that no iron bar can bo placed about a compass in such 2 manner tliat it: deviatiou cannot be expresecd by Archilald Smith's formula. The last part of Captain Creal's paper is perliaps tho nost important, that relating to the cducation of naral Oficcrs on the subject. I am rery plesscd to hear thit it is going on so well, but it lias been going on screral Jcars now, and I'think it is quite time that we got eouncthing out of it. This will nerer be the case unit the Admiralty insist upon naral Odicers putting to practical use the eduestion which it has cost so much to inplpart. If it were once wade clear that Onjeers are expected to adjust the 
compasses of and sning their sbips, cren if the duty were not inmediately mado compulsory, it would be one step towards abolishing the present incficient system. I lo not know that I hare anything else to sar upon the paper, excepting that I think Captain Cresk lias done good serrice in reading it.

Iiniral Cocoun : There were one or two points that struck ne in the reading of the paper. I rather thought the lecturer esplained better than I could, and it scomed satisfactory to my wind, the difference in npparent deriation when the ship is swuen the opposite was, that it ws the time required for the maguctisin of the ship to, as it were, re-assert itself. I hare nerer understoot it before, but it docs secun to me to be a satisfactors explanation. I would ask him in his reply whether that is what has beenealled Gaussin's crror. I would like also if he rrould answer another question. Some time ago there whs a strong correspondence-I jutst saj, that with uns slight bnowledge, to be a rather senseless correspondencein the unceantile marino papers, and I think in the "Nautical Jagazine" also, referring to deriation of the compass in fog. Mlay it not be that in approaching the iand in a fog the sliallow water had aifected the compass, and that the idea arose in that way? Unquestionably all that has been said, speaking prictically; about the necessits for getting some reliable compass in those parts of the ship, where alone in action the command is to be-conning-towers, or whaterer thes may be-is cxecelingly important. Ono is clelighlated to think that we mas be getting hold of souncthing of that sort in this Austriun compass, but I hare nlways felt mysilf, in all theso cascs of the protected command of the slip, that the point is to act ererything out of that place, and to lave nothing but the Oflicer commanding, witl the etaff which it is necesary for him to hare, to hare no instruments whit: eril of any bind inside those places. I. do not know whether anthing lias becn done in the dircetion of rellection, but I cannot help thinking thit we might use the principle to some extent. Sou might move tle cumpass to a suitable distanec and wercly hare the face of it reflected by a scrics of louking-glastes into the place where you want to sce it. To my mind the trouble is analogous to what we hare liat in conreging the words of command, and the telegrapl signals working them from the conning-tower, and $I$ liave always aimed, as long as 1 had power in that way, at getting apparatus away from that place, allowing the Captain's voicc simply, without tubes or anything of the sort, to communicate downwards to the spot where the tolegriphs and tubes and ercrything clsewere, so that he should not be troubled sbont anything execpt giving his orders. In the same may if he had mercls the reflection of the compass before him I think it would be all he would probably require. My own predilections, as faras they go, hare been, I must say, in farour of shifting mignets rather than fised oncs for correcting deriation. I lave alwajs thought very highly of Sir William Thouson's plan, but I am not sure I erer went so fir as to think you should diepense with the standard compass and recording the maguctic changes in the condition of the ship, but I certainly hare fount vuch beneft in haring a compriss whicre you could conlinually correct it on the spur of the noment. For instance, when I was in the Stean Reserve at Portsmouth I liad to tuke ships to sea, knowing nothing of their deriation, and to be at sen for cight or ten hours, lisble, as hilppened to me once or twice, to get into fog, not linowing where rou were or what you could do, with a compass that jou could not trust. The plan I adopted was this. MIy Staff Coumnder laid down a series of transits as we were going outaltcring the slip's head, takine the transits and correcting a Thomson's compass by them, after which we could fairly trust it. At any rite we were in a better cundition from haring a compass that we could correct, howerer roughly, than in bcing caught in a fog at sea without a compass that you could trust at all. I have been cxtrewcly plessed with the lecture, and I only wish that I bad becn more competent to follow it accurately.

Cintain A. C. Parr: Is thic instruction of Oficers at the Faral College at Crecnwich lias been refersed to, $I$, as one who lins becu going througl a courso there, should like to bear testimons to the cxtreme interest which I hare felt in doing so. Before I went there I understood nothing about the compass, and wy instruction with regard to anj corrections has been absolutcly nil. As to bcing able to understand or get any benefit from the $\Lambda$ dmiralty $M a n u a l, ~ I$ am afraid I did not eucced like Admiral Colomb in tracking the murderer to carth at all. I s.n:p.'s 
could not understand it. But now I must say, haring gone through a course of in. struction at the Niaral College, I lare been able to follow this lecture with rery great plensure, and to thank the lecturer for it, and to fecl the benefit which I hav receired from that conrse. I am also very glad indecl that the Sub.Iicutenants ane receiring instruction in the compass, for I think there is the proper end to berin at. If the juirlshipmen know something about it, as they go ou they will be atle to derelop and to obtain rery uscful information. How long the conrse of instruc. tion at the Colleme has been going on I do not know, but certainly we have many capable Oflicers slready instructed, who would be perfectls competent to carry out sus obscrrations tlat might be required, and 1 lave no doubt that we shall rery Foon ece the results which one gentleman who has spoken hopes maj soon be risible. I will conclude by thanking the lecturer for his paper.

Captain Crusis: I miglit suggest to these young gentlemen, the midshipmen, that thes should get a small magnet and experiment witl it. One of the prettiest effects of mannetism is to tikle the kitchen poker, and just hold it in a line nortl and south, at an angle of $67^{\circ}$, give it a blow or two with a mullet or lsammer; one end of it will become the north pole and the otlicr the south, and you then rererse the poler and gire it another blow, and you rererso the poles. I ain sure that such an experiment rould set any midshipman or schoolboy wondering at the effects of wagnet ism and cxcite his curiosity for more hnowledge. I might also suggest, permanent magnetisu is due to the hammering of iron in the manufacture of $a$ stip, and also when slue is twisting and turning about ; the firing of the guns, we suggest is that sub-permanent magnetism is produced. A ship is always altering the magnetism; when she is in the north and south line she increascs it by induecd mannetism of the carth, when she reverses her jicad sbe reverses the current, conscifuently the compasses are always liablo to be corrected, "in fact magnetism is not a constant."

Sir Erasucs OHsaxiex: Might I asb whether any amount of deriation has been deteeted in the magnetic character of a ship during its lifetime?

Admiral Lisprsas I3mise: As I did not heir the whole of the lecture, mliat I an going to eay mas have already been touched upon. The first point I notice is where the lecturer spoke of hecling crror. I do not know whether Captuin Creak means this, but he eays that when a ship heels orer the crror is as much as $10^{\circ}$.

Captain Cresk: I $i$ is somctimes as much as $30^{\circ}$.

Admiral Bnis: : I obserre that in the paper jou $\varepsilon a j$ it gocs up sometimes three points on one side and three points on another. Now as regards this other rery important point about the disturbance of the compass on approaching the land. Fou say in the case of one of jour surreying vessels that running on a certain course you found the compass was "Eteadily dellected $30^{\circ}$ for a quarter of an hour, during which she sailed orer a mile." I suppose that would depend rery much upon the nature of the ground orer which gle was going. Is it bnown what was the nature of the bottom at the point where that ship sailed orcr? Was it rolcanic or some rock of a known cliaracter other than rolcanic? I would also ask the ralue of the rertical at ractiou as compared with horizontal at isaction when a ship is going orcr land nearer the bottom. I hare nerer understood tlat to anj catent the vertical attraction affects the complass in a horizontal dircetion. I suppose that this subject has been worked out. If jou would be bind enough to answer the question it might be uscful.

Captain l3ril.L (Board of Trade) : ds my expericnce is connected entirels with the uercantile uarine, I fear I shall not we able to ach much to the ralue of the discusion, but there are two or three points in the paper I should like to remark upow. Captain MInyes spoke just now about the term "sub-permanent mignetism." Ihat is a point I really do not quito understand in the paper. The officers of the

1 "Some Curiositics of JIaguetism," lecture at the Iondon Institution, Fubruary 11, 18S9, by Shelford Billwell. F.R.S. A rod of iron which has been magnetized bs the action of the magnctic ficld is found generally to retain some of its magnetism when withlrawn from the ficld. This "residual magnetism," as it is called, is held much nore tenaciously bs hard stecl or iron than by metals which lare been softened bs careful aṇealing. 
mercantile warine, and, indeed, nearly all writers on the subject, regard submermanent magnetisun as referring to the permanent magnetism of an iron ship as ilistiuguislicd from the permanent magnetism of a perument magnet, or magnetized stcel var, and consequently they would correct that magnetism with a permanent miguct. Captain Creak appears to appls the tern "sub-parmancnt magnetism" to soucthing between permanent magnetism and transient induced magnetizm, or what is commonly known by tho term "retentire" or "rctained " maguetism. I might esplain mysclf more clearly, perhapa, by referring to two or three extracts $I$ late here. This is from "Torson's Priactical Information on the Deriation of the Compiss, for the use of Masters and JIalcs," a work that nas really prepared as a textbools for the Board of Trade esaninations. Ho remarls : "From irlint linz beera said it will be apparent that the term 'permanent' is not accurate when applied to the magnetism of an iron ship. Dr. Scoresby perecired this, and proposed to designate as 'retentire magnetism' the portion of the magnetism acquired on the building slip, which was retained after launching, and which he considered was retained only for a period, and under certain circumstances might be lost altogether, or cren rerersed. But experience has shown that this is a misapprehension, for although a ship does not retain the whole of the nagnetism acquired on the bnilding Elip, set it is ccrtain that in all our iron ships some portion of tho mangetism so acquired remsins permanent. And we arrec with the Astronomer Rojal, Sir George 3. Airs, in calling this residual magnetisn "sub-permanent magnetism." On the other hand, to put it briefly and clearly, the term is now applied in tho following scnsc in the Nary. This is taken from "The Course of Instruction for Acting Sub. Lieutenants," published by the Admiralty: "Perfectly soft iron as here defined is rare, and the soft iron in ships requires a certain time to fully acquire and lose the induced magnetism. When this time is rery pereeptible-amounting often to many dass-the !magnetism induced is called sub-permanent." It is erident, therefore, that in the Roynl Nary "sub-permnent" refers to induced magnetism, and in tho mercantile marine, and indeed by nearly all writers on the subject, to the permanent mngnetism of the ship. I think it is rather unfortmate that the term "subperwanent," which is so well known, should now be applied to two different, in fact, opposite, things. I may say it was rather confusing to me, although I aun not new at the subject. Therefore, I un sure it must be so to a great many of those who hare but little knowledge of the subject. There is one more point I should like to remark upon, and that is in regard to the following sentence:-Captain Creak says : "It the bridge compiss the quadrantal deviation is only about $5^{\circ}$, and ean be readily corrected by a pair of $z^{\prime \prime}$ spleres, which also help to corrcet about $4 t^{\prime}$ of liecling error for erery dergree of heel on the north und south points till the first $5^{\circ}$ of lieel are rcuched, but gradually decreasing in their porer as correctors as the ship inclincs further." Now, I do not quite see this, but probably I nny not understand the remarks in the sensc intended. It appears to ne that their power as correctors, instcad of decreasing after the ship lieels $5^{\circ}$, is really increaced till she has heeled orcr, say, $25^{\circ}$ or $30^{\circ}$. Put it this way. Suppose jou compensate a quadrantal $+D$ of $5^{\circ}$ by spheres, in the ortinars way. Fou then put the ship's licad north and heel her orer; you would then find when she has hecled orer $5^{\circ}$ that these epheres sould compensate about $2^{\circ}$ of hecling error; at $10^{\circ} \mathrm{hecl}$, about $4^{\circ}$ of hecling error; at $10^{\circ} \mathrm{hecl}$, about $6^{\circ}$; at $\cdot 20^{\circ}$ becl, about $8^{\circ}$; and wlica at $25^{\circ}$ hecl, about $10^{\circ}$. It appears, therefore, to me that it is a continualls increasing power as the ressel gocs orcr instcad of decreasing. I do not know that I liare anjthing further to add, but I should like to be allowed to express my thanks to Captain Creak for his rers: able and intercsting paper.

Colonel Birlis : Would you forgire me for rising to ask a question? I fecl that this lecture is more than usually important, it is one of unirersal interest. 1 baro derired a ereat deal of information from this admirable lecture. There is one point which struek me before coming into this room. It is only perhaps a rudimentary question, and therefore will be most casily answered by the lecturer, and as the Journal goes far and wide throughout the world I think probably what has struck me lins struck others also, and they would like to liare the answer. I know something of the rariation of the compris 3 and the adjustment of the compass, and so on, and it often oceurred to me whether it would ba possible to get some material which 
rill 80 isolate the ship's conmass that it will not be subject to other magnetic pro. pertics or infuences of external matter. The lecturer has stated that the introduction of the electric light on board ship has been a sourec of danger to the euccessful worbin' of the ship's compass, and that experiment has fortunately now shown that mith a well-designed installation all trouble mas be aroided. It occurred to me, before I read this paper or came down here, that eome better method of isolnting the ehip's compass might, set be discorered. If it liad been, it no cloubt would hare been brought into use, but is there any likelihood of some mode being discorered by which you shall be able to isolate the slip's compass that it shall not be liable to be affected by external magnetic propertics, and only the natural magnetic direction prerail? I think that it would be uscful to mysclf and it mag be to others that ing question, though simple to him, should be ansirered by so experieneed a lecturer.

Captain Certis : Ion can isolate clectric wires by gutta-percba, but unlcs jou san get transparent gutta-percha to sec the compass through, I do not sce how you can isolute it. 1

The Cirirnsix : Bcfore ashing the lecturer to answer the questions that lave been put, I intended making a few remarks, but the wind has been taken out of $\mathrm{my}$ sails, for I think thes linre all been touched upon in the discussion. The first onc simply mas as to the possibility of haring a rcliable compass in a conning-lower or in a protected position to stcer the ship by. In a ship of war the important point. is the consideration of what may happen in action. The man at the whecl mas be told to steer a course, but that is no use unless the compass is free from ribration from the concussion of gun-fire. Ire can sce nothing from inside the conning-tower, eren if there is no obscurity from smoke. Therefore he is solely dependent upon the compass. I quite concur that it is improbuble that the Commanding Oficer, under the fire of machine-guns and quick-fring guns, will be able to get at ans other compros outside the conniug-tower, if he docs the chanecs are he will not git back again, and most probably he will find the compass destrojed. I dare eas some of us lecre as midshipmen were rery much puzzlch in shaping a course between the variations to be allowed to the right and deriations to the left, $f e$. , and when we liad to pass csaminations for Licutenants, it was a stumbling block to a great winy of ns. It is a comfort to the younger members of our Service that it is quito possible nowradays that this mas be remored, and we may hare a tolerably pernanent corrected compass to steer by. No doubt on the compass question the sea ecrice of all countrics is rery much indebted to the inrentiro genius of Sir Willian Thomson. I am sorry he is not licre to-day, becanse we should rery much like to hare licard him on this subjeit. The compass, as it appcars to me, is the same as any other scicntific instrument, there can bo no finality in it, and we must go on inproring. As time gocs on, new discorcries are made in magnetism, and new inrentious in construction, as in almost erery other subject. Then we nust remember. this, that different compasses are required for different positions in a ship, and that ono that would be suitable in the conning-tower probably would not be suitable outside. In the conning-torer, what with the iron walls surrounding it and the magnets required forcompensation, it is a wonder to me that you can get the comp $x=3$ card to more at all. The dircetire force of it must be rers high indecl to orercousc all these dificulties. I think after all, the main point comes to this, that the whole question of compass designing and compass construction wust be a mutter for open competition. The inrentire talent of the country must be called upon to combine witl the esperience of the sailor, and asked to adrance. There aro many marine instrument makers in England, and in compass construction competition is as important as in any other trade in the country.

1 At present no substance is buown to isolate magnetism. Vibration or jarring has a remarkable effect in remoring the " residual " mannetism of "soft iron."

I think it redounds to the credit of the Ollicers navigating our men-of-war that not more accidents oceur through the crror of the complisses.

I belicro many merchant slips get embiagcd by shaping their courso too finc from point to point at night, and run ashore, by the crrors of the compass. 
Staff Commander Creak : I must first return my sincerc thanks to the IJjdrogropher for his rery hind remarks witl regard to me in the matter me hare discus:ed. As he las not mate any special remarls cxcept in support of my vicws, I hare nothing to answer. I also thank Captain Jiages for his kind support. Idmiral Colomb asked me onc or two questions. One was about Gaussin's cror; wlucther this difference of deviation resulting from swinging in opposite directions was duc to Gaussin's crror. It bears something of that character, but I really think it ariscs from the cause stated in the paper, though I am not quite satisfied witl wliat I have said about it. A certain amount of iron in the ship parts with its nuszetism instantly, the same 23 when rou roll $a$ soft iron sphere mpidly on a table, nnd no trace of mannctism is carried round with it; but there is another kind of iron in the ship which is not quite so soft, and take3 some littlo time to part with its mannctism. I think that is really the causc of the deviation being different when swinging different ways. Then with regard to fog. The Captain of ah merchant ship, with whom I was onco talking complained that he was constantls being troubled with the cifect of fogs on his compass in the lialtic. I nsked him to try it systematically, and to send me the result when he eane back. IIe was to go to some place in the Baltic and lay alongside the quay; when there to note whether. the comprass altered after for liad come on, and then I sliould beliere in it. II never could tell me such was the casc. I found it simply arose from this fact: wlien they were stecring up amongst the rarious islands in the Baltic, as long ns it was clear weather, although the man at the helm often let the resirl fall off her course, the land being alirays in sight, tho Cuptain could luul up a point or so, ay requircl. After the fog came on the helnisnian stecred no better, whilst tho Captain's correctire for the bad stecring was no longer arailable, and the fog was blamed. I belicre that is the sole camsc. We know that the most delicately consiructed instrunents at Kew are in no was affected by the fog. Redection applied to the compass is another quastion. I do not see how it is to be done. I think if you come to think of the smoke with which we should be surrounded in action, we should hardly sce ang rellection. Stcam cspecially lias a rerg bad cficet upon all reflectors. Filicy liave often been proposed, but i can sce no way to the use of rellectors. I quite agree with what Almiral Colomb said about the frequent corrections of the mancurring compass, and the au siliars compasses used for stecring might be corrected ns often as desired, and Commanding Oficers should gire an opportunity for it to be done. I lnow in some ships the complaint is made, "Why" is the compass not correct ?" and the answer has been, "You hare not giren me tho opportunity of correcting it." The magnetism of the iron of a ship is liable to clianges, and the deriation of the compuss must chinge in obedience to them; thereford there wust be constant correctiou. Captain Parr has made some well-deserred remarks about the instruction at Grecnwich. I am glad to hear he is sitisfied with it, and I dare say lic will be realy for the next esmmination when it comes on. I must also thant Admiral Onmannes for his kind rewarks about this paper. Respecting the change of magnetiom of a shin, I must say that there is a definite character impressed upon her in building which is nerer lost. Allmiral briue $2: k 5$ about tho heeling crror. I'criaps I have not made mysclf perfectly elear ou that question. What I mean is if you take the Ineling crror of $1^{\circ} 10^{\prime}$ obtuiued for the standard comp:s3s of the "Orlando," by actual iuclination of the ship for $1^{\circ}$ cither to starboarl or port on north and scith courscs, then, if that ship were inclined $10^{3}$, thero sould be $11^{\circ}+0^{\prime}$ of hecling error.

Admiral Brise: That would be constant all through.

Captain Cnesk: No, it would alter as the cosiuc of the azimuth of the slip's heal, and nould be zero at E. Toke X.E., the internediate point, for cranple, sou would hare to anuliply the $11^{\circ} 40^{\prime}$ bs $0 \cdot 7$, nnd you would get as result a hecling error of about $8^{\prime}$ lo $0^{\prime}$ on tinat point. I nay sas with regard to the remarkable disturbance of the compass at Cossact, Australia, that unfortunately the "IIcln" did not return there, and thercforo us full an csamination of the spot was not made ag was desirible, though the best was done in the time arailable. Tho whole of that part of Australia is rery highly magnctic. There are ferruginous rocks in eereral parts of Australia ; in fact one may observe the red lines passing through the sandstone rocks, many of them rery highly magnetic. With regard 
to the rertical force of these rocks where the compass is concernct, the only thing to be fanred is a possible horizontal componeut to their tolal deflecting power. Ciptrin beall male some remarks about sub-permanent magnetism. The word "retentire" I hare nerer taken to. "Retentire" means sonething that is liept, not plirted witl ; but "retentire nngnetism" in the was we sec it described in the books is anstling but retentire in the natural meaning of the vord.

Captain i3esxa: I s.3y rou call "permanent" what we call " retentire."

Ciptain Cuesk : I am only spealing of the word "retentirc." Nor with regard to the word " sub-permanent" I think that is another matter, in whicls we nuat more a little with the tincs. When the Astronomer llogal adopted the word "sub-permanent" it was his opinion that the whole of the magnetism of the ship was more or less sub-permanent and not pernanent. I3f. the inrejtigitions I liare slown in the carly part of the paper almost the whole of the magnetisu of our men-of-war is permanent, so whycill it sub-permanent? I epeak of sub-permanent magnctism which has the character of permanent magnetisn in a mensurc, but is subject to constant change either from running on one courso or from the blows of firing guns not rarious other causcs. With regind to the hecling error cuusel by splicres, I have made experiments with $8 \frac{1}{2}$-inch spheres attacheil to a Tliomson binnacle, nnd found that if rou incline that binnacle, for tho first $5^{\circ}$ of inclination there is a liceling error of $53^{\prime}$ for cach degree of licel; for the first $10^{2}$ nbout $50^{\circ}$, and if you incline it to $30^{\circ}$ rou will find it is $20^{\prime}$ for tho list $5^{\circ}$ of heel. I conclude, thercfore, that whilst the liecling error is a constant quantity and goes on incressing cqually for cress degree of liecl till $30^{\circ}$ is reached, the effect of the globes as corrcctors is a climinishing quantity.

Captain BEALr: I understood Captain Creak to mean that, supposing for the sake of clearncss the heling crror were a constant quantity, say $t^{2}$, then, if the resicl hecled orer more than $5^{\circ}$, the splieres would not be so powerful, or in other roods would not compensate the supposed constint crror of $4^{\circ}$. J3ut perlapis I mas hare misunderstood Captain Creak, and he means to conrey that ther decrease in power proportionately to the lieel of the ship, but cren then it rould appear from tho figures giren in my remarks, which were obtained from act unl experiment, that the decrease would in some cases be rery small, if any. I found that spheres (about $-t^{\prime \prime}$ ) which corrected a $+D$ from athwartship iron alone, ulso just corrected the hecling crror causcd by the same irou up to $25^{\circ}$ of hecl; and no doubt rould do so bejond that.

Captain Crmak: What I mcan es2ctly is this, that the globes do not do as nucin work at the estreme heel of $30^{2}$ or $10^{\circ}$ as they do during the first $5^{\circ}$. Then, with regurd in the point mentioned bs Colowel Baylis, asking whether some insulating substance cannot be internosed to climinate the magnetic effect of the ship on the compass; that has been tricd by sercral pcople. Some hare tricd it by using soft iron and rarious other substances, but we know perfectly nell it cannot be done. The dircetire porrer upon the compess is the curth, ind we hare alresely juterposed between the compass and thic carth a rery big manget and a lot of surall innernets in the slinpe of a ship, and her fittings, as wcll 25 arwour-plating of soft iron, which adds to the diflicult $y$. I know of no substance which can he initerposed betricen the compass and the ship which does not isolate it from the dircetive foree of the carth. I nin rery glad to hear that our Chaiman belieres that there is no finulity in tlic question of compasses, and that anybody, no matter who lie may be, who will bring forward sone improrement, should be courtcously entertained and his proposals fully gone into, and, if good, sdopted. I should not lihe to sit down witlout miking one remurk with regard to the Constructive Department of the Admiralty, and nelinowledge the ready manner in which the Director of Paral Construction nnd his whole staff meet me in crers way, by affording ne crery fncility for currying out expariments or desirable improrements in the disposition of the compases in our ships. I liare also to return my thanks for the bind attention with which my piner ling been receired.

The Cinsinsiax: I meint to hare referred to the question of the reflector for compasses, raised br Admiral Colonb. I hare had soine experience with reflectors with referenec to gun-fire, and found thes were alwass dim on bourd ship nnd generills out of order. They hare nerer been able to stand the shock of gun-Gire. 
I remember on one occasion at Shocburyness the disappearing gun mas being fired with reflecting sights. 'The cajtain of the gun looked up orer heal into the redlector which was abore the parapet. The gun was fired and crerybody looked out towards the target, 1,500 yards off, but instead of the shot striking the water near the target, we found the gui had becn pointed nbout $45^{\circ}$ to the left, and the shot had gone through the roof of a shed in that direction owing to the reflector laving got clisturbed. It now clerolres upon mo to return our thanks to the lecturer for his aclmirable lect ure which had led to at rery interesting discussion.

1'S.-I can bear testimony as to the efliciencs of the liquid compass for boat scrrice; forty years ago one liquid boat conploss vias supplicel to the flag-ehip on the licst Coist of $\lambda$ frica. Boat eruizing after slares was carried on to a consider. able extent mostly out of eight of lind. This liquid compass was the only one that was of any usc when rowing lard or in a sea-was, all others would ribrate three or four points off the course each may.-II. 13 . 